\title{
Intraspecific diet shifts of the sesarmid crab, Sesarma dehaani, in three wetlands in the Han River estuary, South Korea
}

\author{
Dongwoo Yang ${ }^{1,3}$, Donguk Han ${ }^{2,3}$ and Sangkyu Park ${ }^{1 *}$ (D)
}

\begin{abstract}
Background: Han River estuary is a national wetland reserve near the Demilitarized Zone (DMZ) between South Korea and North Korea. This trans-boundary estuary area has been well preserved and shows distinctive plant communities along the salinity gradient. To elucidate energy flows and nutrient cycling in this area, we studied trophic relations between the dominant sesarmid crab, Sesarma dehaani, and food sources in three wetlands with different environments along the estuarine gradients.

Results: Stable isotope signatures $\left(\delta^{13} \mathrm{C}\right.$ and $\left.\delta^{15} \mathrm{~N}\right)$ of the crabs were significantly different among the sites and body size classes. Seasonal changes in $\delta^{13} \mathrm{C}$ of small crabs were distinct from those of large individuals at all the sites. The isotopic values and fatty acid profiles of the crabs were more different among the sites in September than in May. In May, large-sized crabs utilized more plant materials compared to other dietary sources in contrast to small-sized crabs as revealed by a stable isotope mixing modeling, whereas contributions to diets of crabs were not dominated by a specific diet for different body size in September except at site 1. Based on PCA loadings, fatty acid content of 18:3 03 , known as a biomarker of plant materials, was the main factor to separate size groups of crabs in May and September. The $\delta^{13} \mathrm{C}$ value of sediment had high correlation with those of small-sized crabs at site 1 and 2 when 1-month time lag was applied to the value for crabs during the surveyed period.
\end{abstract}

Conclusions: Based on the stable isotope and fatty acid results, the consumption habits of S. dehaani appear to be distinguished by sites and their size. In particular, smaller size of S. dehaani appears to be more dependent on fewer food sources and is influenced more by the diet sources from the sediments in Han River estuary.

Keywords: Sesarma dehaani, Stable isotopes, Fatty acid biomarkers, Diets shift, Han River estuary

\section{Background}

To elucidate ecosystem functions, such as energy flows and nutrient cycling, it is essential to understand the trophic relations of dominant organisms in food webs (Vander Zanden et al. 2006). The food webs in estuaries are complex; they incorporate different environments, such as terrestrial and brackish environments, and provide diverse habitats as well as different food sources for various organisms based on hydrological fluctuation (Peterson 1999; Nagelkerken et al. 2008; Kristensen et al. 2008). Numerous studies on estuarine food webs have been conducted for comparisons with habitats with a

\footnotetext{
* Correspondence: daphnia@ajou.ac.kr

'Department of Biological Science, Ajou University, 206, World cup-ro,

Yeongtong-gu, Suwon 16499, Republic of Korea

Full list of author information is available at the end of the article
}

salinity gradient from riverine mouth to offshore, possessing different vegetation types (Lee 2000; Doi et al. 2005; Choy et al. 2008; Antonio et al. 2012; Bergamino and Richoux 2015). Several studies have focused on food webs in mangrove systems in subtropical and tropical regions (Kristensen et al. 2008; Lee et al. 2014); they have especially focused on the interactions between mangroves and crabs, such as grapsid and sesarmid crabs, which have been reported to be major players in carbon cycling in these systems and primarily consume mangrove litters and propagules (Lee 1998).

Han River estuary is a national wetland reserve near the Demilitarized Zone (DMZ) between South Korea and North Korea (Han et al. 2010). This trans-boundary estuary area between North and South Korea has been well preserved and shows distinctive plant communities

(c) The Author(s). 2019 Open Access This article is distributed under the terms of the Creative Commons Attribution 4.0 International License (http://creativecommons.org/licenses/by/4.0/), which permits unrestricted use, distribution, and 
along the salinity gradient (Park 2004). Although the Han River estuary ecosystems exhibit great temporal and spatial variations, only limited studies have been conducted on these due to confrontation between South and North Korea, especially on wetlands in the upper brackish area (Han et al. 2010, 2012). A previous study on a wetland in the upper brackish area in the Han River estuary revealed that the wetland was supported by both tidal allochthonous organic matter accumulated on sediment and primary production from marsh plants. In addition, its food web was observed to be dominated by an omnivorous crab species, Sesarma dehaani (Han et al. 2010). The crabs showed diverse feeding preferences, depending on their sizes, in the wetlands in the upper brackish area dominated by riparian plants, Salix species. The young crabs were observed to depend on limited food sources, mainly detrital sediment, whereas the older individuals appeared to use diverse food sources, such as plant material and their own species, in addition to the detrital sediment (Han et al. 2012). Several studies have been conducted to demonstrate that the trophic relations of sesarmine crabs contribute to nutrient cycling in the estuarine ecosystems, especially in mangrove ecosystems, with spatial differences and seasonal changes (Kyomo 1992; Werry and Lee 2005; Thongtham et al. 2008; Poon et al. 2010; Kristensen et al. 2017). However, only a few studies have considered the size of crabs in relation to their food selection (Buck et al. 2003; Pahlas 2013).

In this study, we extended our previous investigation wherein we elucidated trophic relations between the sesarmid crab, S. dehaani, and food sources, particularly plant material and sediment, with respect to the size of crabs in the upper brackish areas, to three wetlands dominated with different plant species along the estuarine gradients in the Han River. In this regard, we estimated the diet contributions of the crabs, grouped by size, based on carapace width and seasonal change using stable isotope and fatty acid analyses with a stable isotope mixing model in three different sites with different vegetation and marine influence.

\section{Materials and methods Study area}

The Han River runs through the middle part of the Korean peninsula, penetrating through Seoul to reach the Yellow Sea. The Han River estuary lies inside the Demilitarized Zone (DMZ) between South and North Korea $\left(37^{\circ} 36^{\prime} 56^{\prime \prime} \mathrm{N}, 126^{\circ} 47^{\prime} 38^{\prime \prime} \mathrm{E}\right.$ to $37^{\circ} 46^{\prime} 36^{\prime \prime} \mathrm{N}, 126^{\circ}$ $31^{\prime} 34^{\prime \prime}$ E). We studied three different wetlands encompassing a spatial gradient of environmental conditions. The Janghang wetland, containing site 1 , is located $31.7 \mathrm{~km}$ upstream of the river mouth, whereas the Gongreung wetland, containing site 2, and Seongdong wetland, containing site 3 , are 18.3 and $14.4 \mathrm{~km}$ upstream, respectively (Fig. 1). The upper parts of the Han River estuary showed salinities less than 1.7, with a tidal range of $\sim 3$, whereas salinity in the lower part ranged between 2.8 and 8.2, with a tidal range of 6.8 (Park 2004; Baek and Yim 2011). The mean air temperature is less than $0^{\circ} \mathrm{C}$ during winter season, whereas it increases to $25^{\circ} \mathrm{C}$ in summer in the Han River estuary encompassing the sampling sites (Ministry of Environment Korea 2007). Rainfall mostly occurs in

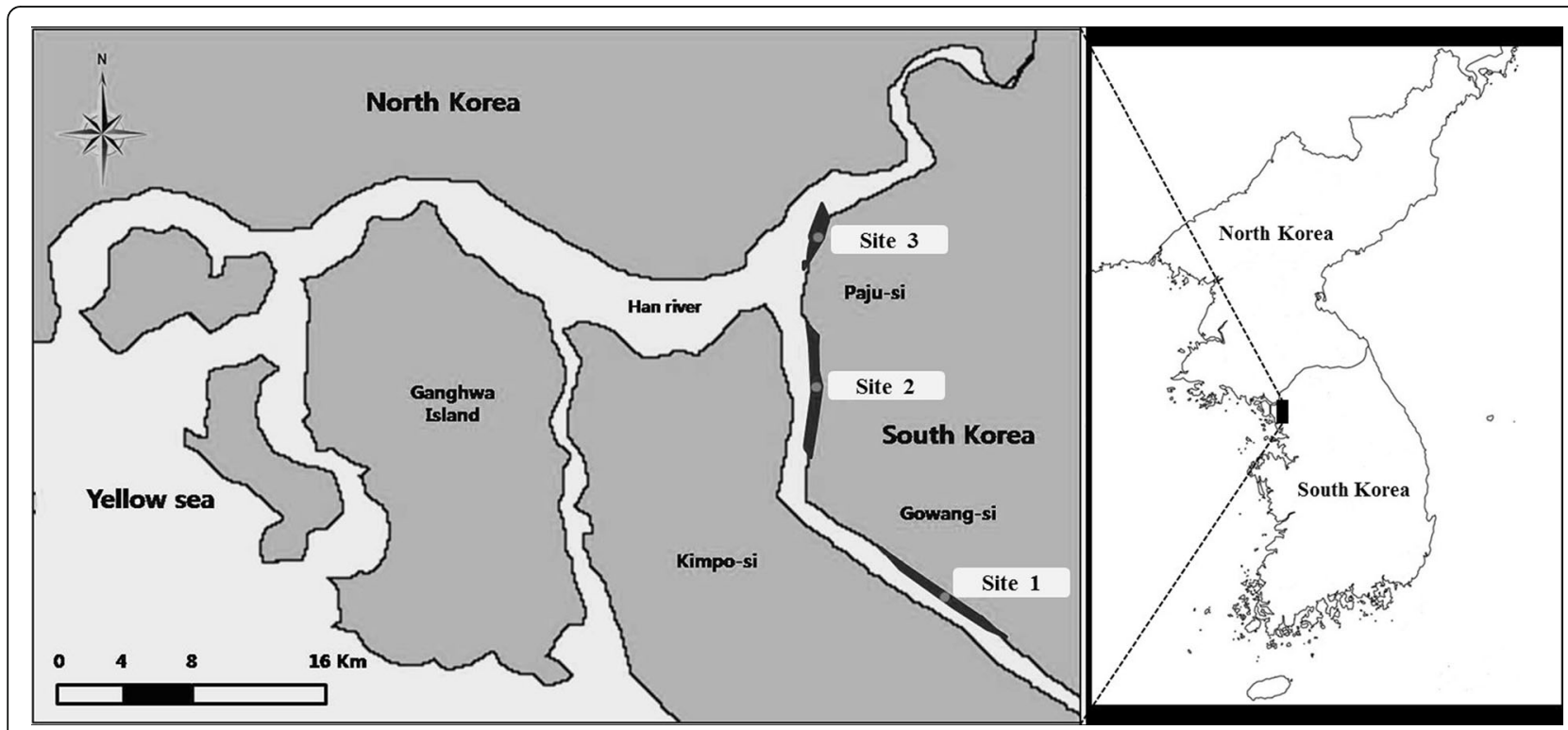

Fig. 1 Location of sampling sites in the Han River estuary, South Korea: site 1 (Janghang wetland), site 2 (Gongreung wetland), and site 3 (Sungdong wetland) 
summer, particularly in July and August, in these areas contributing up to $60 \%$ of the annual total precipitation. Each part of the estuary contains distinctive wetlands with different plant species and decapod species. The site 1 is dominated by Salix subfragilis and the estuarine sesarmid crab, S. dehaani. In site 2, Phragmites communis dominates along with the sesarmid and a marsh crab, Helice tridens. The emergent vegetation in the site 3 is dominated by Bolboschoenus planiculmis and P. communis along with the sesarmid and an intertidal dotillid crab, Ilyoplax deschampsi. Among the invertebrate benthic fauna, $S$. dehaani is dominant or subdominant species in the Han River estuary and inhabits all the study sites. The access of citizens to site 1 and 3 had been restricted by the military.

\section{Sample collection and preprocessing}

The sesarmid crab, the characteristic marsh plants $(S$. subfragilis for site $1, P$. communis for site 2 , and B. planiculmis and $P$. communis for site 3 ), and sediment were collected from the three sites every month between August 2006 and November 2007 except during the winter season (November 2007 for site 2 and October and November 2007 for site 3) when the crabs hibernated in their burrows and access to them was restricted. The crabs caught by hand from each study area were classified into four size groups, namely group I $(\sim 10-20$ $\mathrm{mm})$, group II $(\sim 20-30 \mathrm{~mm})$, group III $(\sim 30-40 \mathrm{~mm})$, and group IV (larger than $40 \mathrm{~mm}$ ), based on its carapace width. The sediment samples were collected by gently scraping the sediment surface (typically $0-5 \mathrm{~mm}$ from the surface). The microphytobenthos (MPB) and allochthonous organic matter were not completely removed from the sediment. So the detrital sediment samples contained a portion of both materials. The fresh leaves of marsh plants were collected at each site by cutting the leaves. The collected samples were transported at low temperature in iceboxes to the laboratory. The crabs were killed by freezing at $-20^{\circ} \mathrm{C}$, and the white muscle tissue inside the carapace and chelae was separated for analyses in the laboratory. For the smallest size group, tissue from two individuals was pooled to obtain sufficient biomass. The leaves were rinsed with distilled water. All the samples were stored in a deep freezer at $-80^{\circ} \mathrm{C}$ until they were used in subsequent procedures.

\section{Stable isotope analysis}

All the samples were dried using a freeze dryer (Model FD2.5; Heto, Waltham, USA). The freeze-dried samples were further dried at $60^{\circ} \mathrm{C}$ in an oven for $48 \mathrm{~h}$ and subsequently ground into powder using pestle and mortar. The ground samples were wrapped in tin discs (Perkin Elmer, Waltham, USA) as compact spheres with a maximum diameter of $6 \mathrm{~mm}$ and were stored in well plates until the analysis. Most of the samples were analyzed at the Center for Stable Isotope Biogeochemistry at the University of California, Berkeley, USA, using a Delta Plus XL isotope ratio mass spectrometer (IRMS, Thermo Finnigan, Germany). Some samples of detrital sediment and plant materials were analyzed at the Cooperative Center for Research Facilities at Hanyang University, Korea, using an interfaced continuous-flow isotope ratio mass spectrometer (EuroEA-Isoprime IRMS, GV instruments, UK). Few samples were analyzed to compare the isotope signatures obtained using the different instruments. No significant difference in $\delta^{13} \mathrm{C}$ and $\delta^{15} \mathrm{~N}$ values was observed between the instruments.

The $\delta^{13} \mathrm{C}$ and $\delta^{15} \mathrm{~N}$ values were expressed as differences (in parts per thousand, \%) in ${ }^{13} \mathrm{C}:{ }^{12} \mathrm{C}$ and ${ }^{15} \mathrm{~N}:{ }^{14} \mathrm{~N}$ ratios $(R)$, respectively, between the samples and the standards [Pee Dee Belemnite marine limestone for ${ }^{13} \mathrm{C}$ and atmospheric nitrogen for ${ }^{15} \mathrm{~N}$ ], as follows:

$$
\begin{aligned}
& \delta^{13} \mathrm{C} \text { or } \delta^{15} \mathrm{~N}(\%)=\left[\frac{R_{\text {sample }}-R_{\text {standard }}}{R_{\text {standard }}}\right] \times 10^{3} \\
& R={ }^{13} \mathrm{C} /{ }^{12} \mathrm{C} \text { or }{ }^{15} \mathrm{~N} /{ }^{14} \mathrm{~N}
\end{aligned}
$$

From each size class, one to four crabs were randomly selected for stable isotope and fatty acid analyses from among the samples caught in the fields.

\section{Fatty acid analysis}

The frozen samples were dried in a freeze dryer and ground using pestle and mortar before extraction. The freeze-dried samples were weighed using an electronic balance (Model A120S; Sartorius, Goettingen, Germany), and the weighed samples were wrapped in glass fiber filter paper $\left(\mathrm{GF} / \mathrm{C}\right.$, Whatman) pre-combusted at $400{ }^{\circ} \mathrm{C}$ for extraction. The extraction and methylation were performed using a method modified from Kattner and Fricke (1986). Heneicosanoic acid (21:0) was added to each sample as an internal standard $\left(1 \mathrm{mg} \mathrm{ml}^{-1}\right.$ in methanol). The extracted fatty acid methyl esters (FAMEs) in hexane were kept at $-80{ }^{\circ} \mathrm{C}$ until further analysis. The FAMEs were analyzed using a gas chromatograph (Agilent, Santa Clara, USA, 6890N) equipped with a programmable temperature vaporizer (PTV) and a flame ionization detector (FID). The FAMEs were readily separated on a capillary column (DB-Wax: $30 \mathrm{~m}$, $0.32 \mathrm{~mm}$ id, $0.25 \mu \mathrm{m}$ film thickness, Agilent, USA). Five microliters of each FAME sample was automatically injected using an Agilent 7683B Series injector. The temperature of PTV was programmed to increase from -40 to $250^{\circ} \mathrm{C}$ within $2 \mathrm{~min}$ using liquid nitrogen and then held at $250^{\circ} \mathrm{C}$ during the analysis. Helium was used as the carrier gas, and a constant pressure ( 8.6 psi) mode 
was applied. The oven temperature was set at $40{ }^{\circ} \mathrm{C}$ for 5 min after injection and was programmed to increase to $150{ }^{\circ} \mathrm{C}$ at a rate of $10^{\circ} \mathrm{C} \mathrm{min}^{-1}$ and was then held at 150 ${ }^{\circ} \mathrm{C}$ for $5 \mathrm{~min}$; it was then increased to $220^{\circ} \mathrm{C}$ at a rate of $2{ }^{\circ} \mathrm{C} \mathrm{m^{-1 }}$ and held at $220^{\circ} \mathrm{C}$ for $24 \mathrm{~min}$. The FID was held at $250^{\circ} \mathrm{C}$ during the analysis. The FAMEs were identified by comparing their retention times with those of the standard mixtures (37 Component FAME Mix, Supelco, Cat. No. 47885-u and marine source FAMEs, Sigma-Aldrich, Cat. No. 47033). The fatty acids were quantified by comparing the ratios of the area under the peaks of the samples to those under the peaks of the internal standard, using an Agilent ChemStation software.

\section{Data analysis}

The body size and spatial difference in the stable isotope signatures of $S$. dehaani captured in all the seasons were identified by performing a two-way analysis of variance (ANOVA). This analysis used "size group" and "site" as the two factors. Principal component analysis (PCA) was conducted to compare the fatty acid compositions of crabs among the size groups and habitats. Prior to PCA, log transformations were applied to ensure the homogeneity of variance; this was followed by Pareto scaling to improve the fatty acid information content (van den Berg et al. 2006). To compare the stable isotope signatures and fatty acid (FA) profiles of the crabs between the size classes and among sites, multivariate analysis of variance (MANOVA) was conducted (Cherel et al. 2000; Delaporte et al. 2005). MANOVA can examine whether the averages of the combined values of $\delta^{13} \mathrm{C}$ and $\delta^{15} \mathrm{~N}$ or PCA score of FA profiles are significantly different between the size groups or among sites. The stable isotope analysis in R (SIAR) package (Parnell et al. 2010), one of Bayesian stable isotope mixing models, was used to estimate the source contributions to the diets of $S$. dehaani in different sites between the two seasons (May provided a short time to feed after hibernation and September was the period of more feeding compared to spring). For running the model, $\delta^{13} \mathrm{C}$ and $\delta^{15} \mathrm{~N}$ values of the crabs and diets, such as plant material and sediment, collected in both May and September were used. The stable signatures of MPB, assumed as one of diets applied, were from the global averages $\left(\delta^{13} \mathrm{C}:-20.2 \% \pm 2.1 \%\right.$ and $\delta^{15} \mathrm{~N}: 2.4 \%$ o $\pm 1.2 \%$ ) compiled from various habitats (Kristensen et al. 2017) because of incomplete sampling in this study. The discrimination factors of the diets were referred to the previous study. For sediment and MPB, the universal trophic values, $0.4 \%$ for $\delta^{13} \mathrm{C}$ and $2.3 \%$ for $\delta^{15} \mathrm{~N}$, were used (McCutchan et al. 2003). The values of $\Delta^{13} \mathrm{C}$ at $3.5 \%$ o $\pm 1.5 \%$ and $\Delta^{15} \mathrm{~N}$ at $4 \%$ o for plant materials that the sesarmid crab fed on mangrove leaves were applied (Kristensen et al. 2017). The Spearman rank correlation was employed to validate the feeding ability of $S$. dehaani on sediment by comparisons of $\delta^{13} \mathrm{C}$ of both the sediment and crabs in the different sites in all the seasons. All statistical analyses and modeling were performed with S-Plus 6 for Windows (Insightful Corp., Seattle, USA) and R (R Core Team 2014).

\section{Results}

Isotopic signatures of Sesarma dehaani during the entire period

The results of the two-way ANOVA on stable isotope signatures of $S$. dehaani sampled during the entire period of study revealed significant differences among the crab size classes and among the different sites. The percent of variance explained by the site factor was higher than that explained by the size factor on both $\delta^{13} \mathrm{C}$ and $\delta^{15} \mathrm{~N}$ of $S$. dehaani, especially on $\delta^{15} \mathrm{~N}$ (Table 1). The $\delta^{13} \mathrm{C}$ and $\delta^{15} \mathrm{~N}$ values of the crabs were respectively within certain ranges for each site: $-25.2 \%$ \pm 1.2 and $8.3 \%$ o $\pm 1.0, n=174$ at site $1 ;-24.6 \%$ o \pm 1.6 and $9.7 \%$ $\pm 0.9, n=62$ at site 2 ; and $-22.0 \%$ a \pm 2.3 and $11.3 \% \pm 1.0, n=58$ at site 3 (Fig. 2).

\section{Diet source contributions by size groups in two seasons}

To compare the effect of the surrounding circumstances on the contributions of diet to $S$. dehaani in detail, we selected two seasons for the analyses. The season during May provides a short time for the utilization of diets after hibernation, and the season during September provides more time for feeding as well as a wide range of diets compared to the spring. In addition, the monsoon rainfall during the summer influences their feeding between the two seasons.

Our results showed that variations in the $\delta^{13} \mathrm{C}$ and $\delta^{15} \mathrm{~N}$ values of the crabs were much larger in September than in May in 2007, especially at site 2 and 3 compared to that at site 1 (Fig. 3). The variations in the $\delta^{13} \mathrm{C}$ and

Table 1 Results of two-way ANOVA comparing the impacts of size groups (group) and habitats (site) of Sesarma dehaani on the values of $\delta^{15} \mathrm{~N}$ and $\delta^{13} \mathrm{C}$ for the entire period of study

\begin{tabular}{lrrrr}
\hline Source & df & $F$ & $p$ & \% of variance explained \\
\hline$\delta^{15} \mathrm{~N}$ value & & & & \\
Group & 3 & 10.87 & $<0.001$ & $3.70 \%$ \\
Site & 2 & 270.01 & $<0.001$ & $60.60 \%$ \\
Group $\times$ site & 6 & 5.88 & $<0.001$ & $4.00 \%$ \\
Residual & 283 & & & $31.80 \%$ \\
& & & & \\
$\delta^{13}$ C value & & & & $3.00 \%$ \\
Group & 3 & 5.40 & 0.001 & $40.70 \%$ \\
Site & 2 & 108.41 & $<0.001$ & $3.00 \%$ \\
Group $\times$ site & 6 & 2.68 & 0.015 & $53.20 \%$ \\
Residual & 283 & & &
\end{tabular}




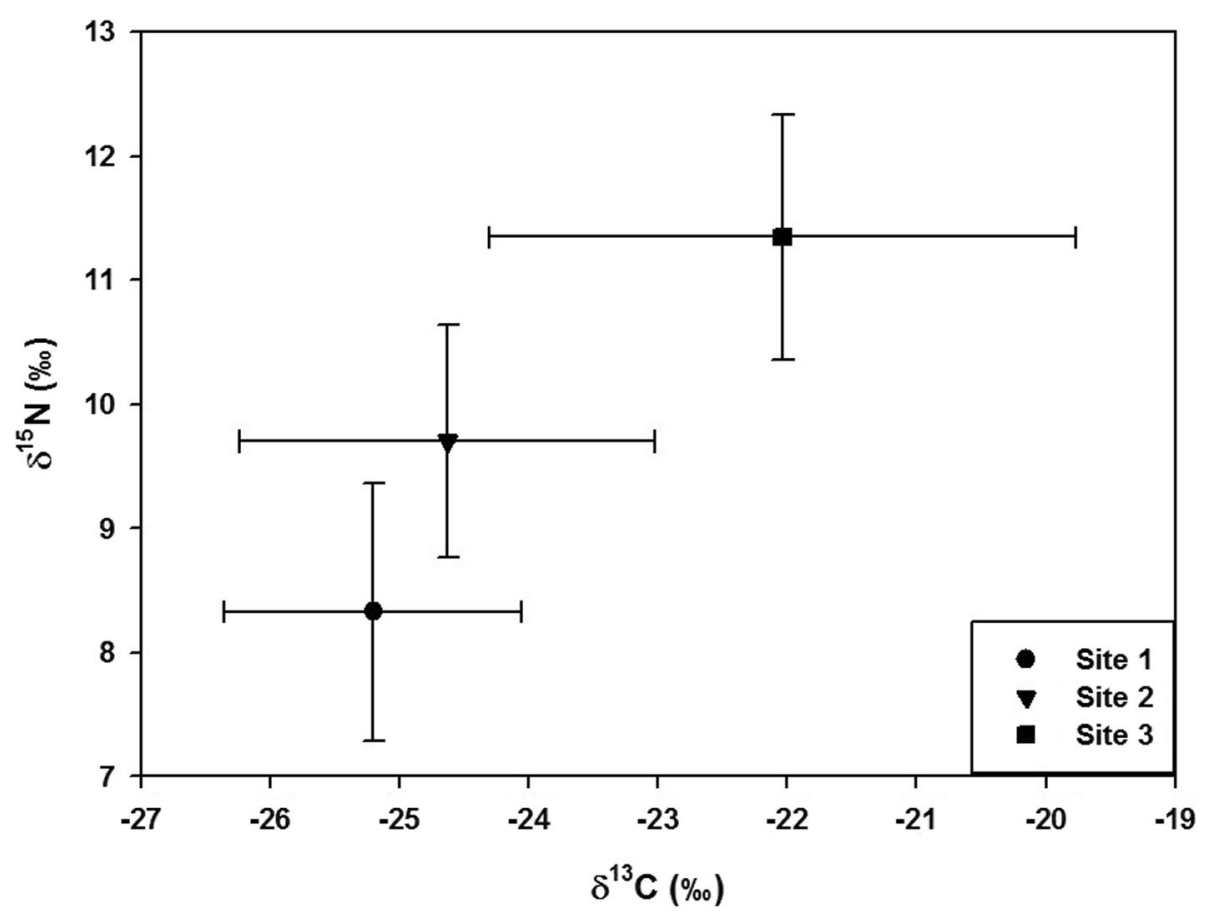

Fig. 2 Dual isotope plots of $\delta^{13} \mathrm{C}$ and $\delta^{15} \mathrm{~N}$ mean values $( \pm \mathrm{SD}$ ) for all sized groups of Sesarma dehaani at site 1, site 2, and site 3 in the Han River estuary in whole study period

$\delta^{15} \mathrm{~N}$ values of the crabs were larger in small individuals (group I and II) among the different sites, in September compared to those in May (Table 2, MANOVA, $p<0.001)$. The stable isotope signatures in small individuals exhibited much larger variations in September at all the three sites, whereas those in large individuals (group III and IV) were relatively similar.

The contributions of potential food sources for S. dehaani exhibited spatial and temporal variations, and they also showed ontogenic shifts as revealed by the results of the stable isotope modeling (Fig. 4). At site 1, the mean percent contribution of plant material increased along with size in contrast to that of the sediment in both May and September. At site 2, a similar pattern was observed in May, whereas the contributions of diets were not characterized by size classes in September. At site 3 , the potential food sources evenly contributed to the diets of the crabs in all the size ranges except those in group I and II in September.

The principal component analysis showed that the FA profiles of $S$. dehaani differed among the individuals in the different size classes at sites 1 and 2 in May 2007 (Fig. 5a). In September 2007, the FA profiles were clearly different between the individuals from site 3 and site $1 / 2$ (MANOVA, $p<0.05$ ). In addition, there were differences between the different size groups at each site (Fig. 5b).
Trophic relations between sediment and Sesarma dehaani Comparisons of the $\delta^{13} \mathrm{C}$ values of both the sediment and S. dehaani revealed that the values for individuals in group I and II were closer to those of the sediment compared to those of group III and IV (Fig. 6). However, correlations between the $\delta^{13} \mathrm{C}$ values of sediment and those of $S$. dehaani were not significant (Spearman rank correlation test: $p>0.05)$ at different sites and in different size classes. When a time lag of 1 month was applied in determining the $\delta^{13} \mathrm{C}$ values of $S$. dehaani and those of sediment, considering the turnover rates of carbon from food sources, strong positive correlations were observed in the values for sediment and small $S$. dehaani individuals at site 1 and site $2\left(p=0.035, r_{s}=0.68\right.$ and $p=0.048, r_{s}=0.79$, respectively). In contrast, there was no significant relation in the values for small crabs and sediment at site 3 .

\section{Discussion}

The results of this study suggest that the consumption of food by the sesarmid crab, S. dehaani, was influenced by the landscape heterogeneity. Moreover, shifts in the feeding habits of $S$. dehaani between the size classes in the lower brackish area (site 3), which was less vegetated, were unclear compared to those in the upper area (site 1), which was densely forested by the Salix 


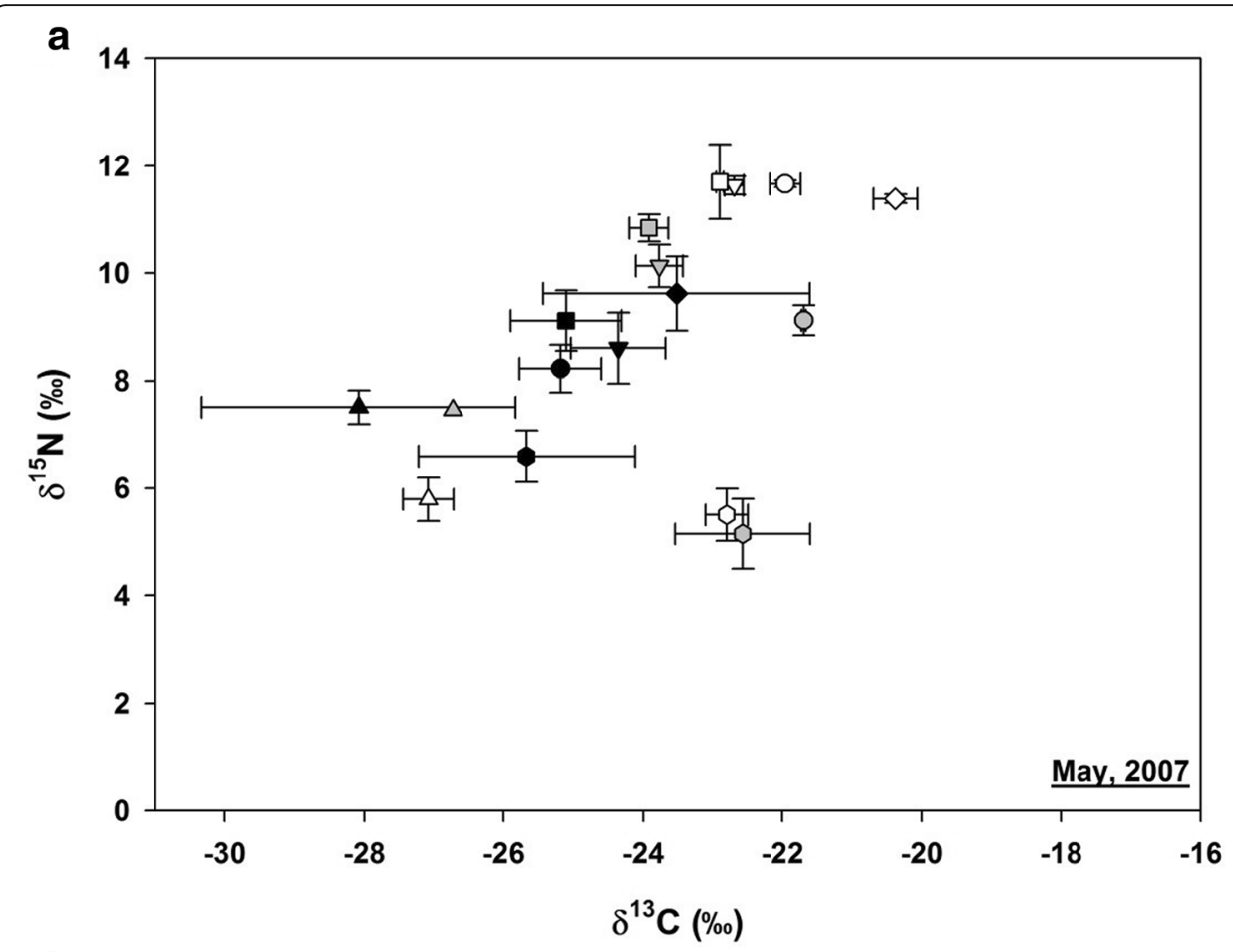

b

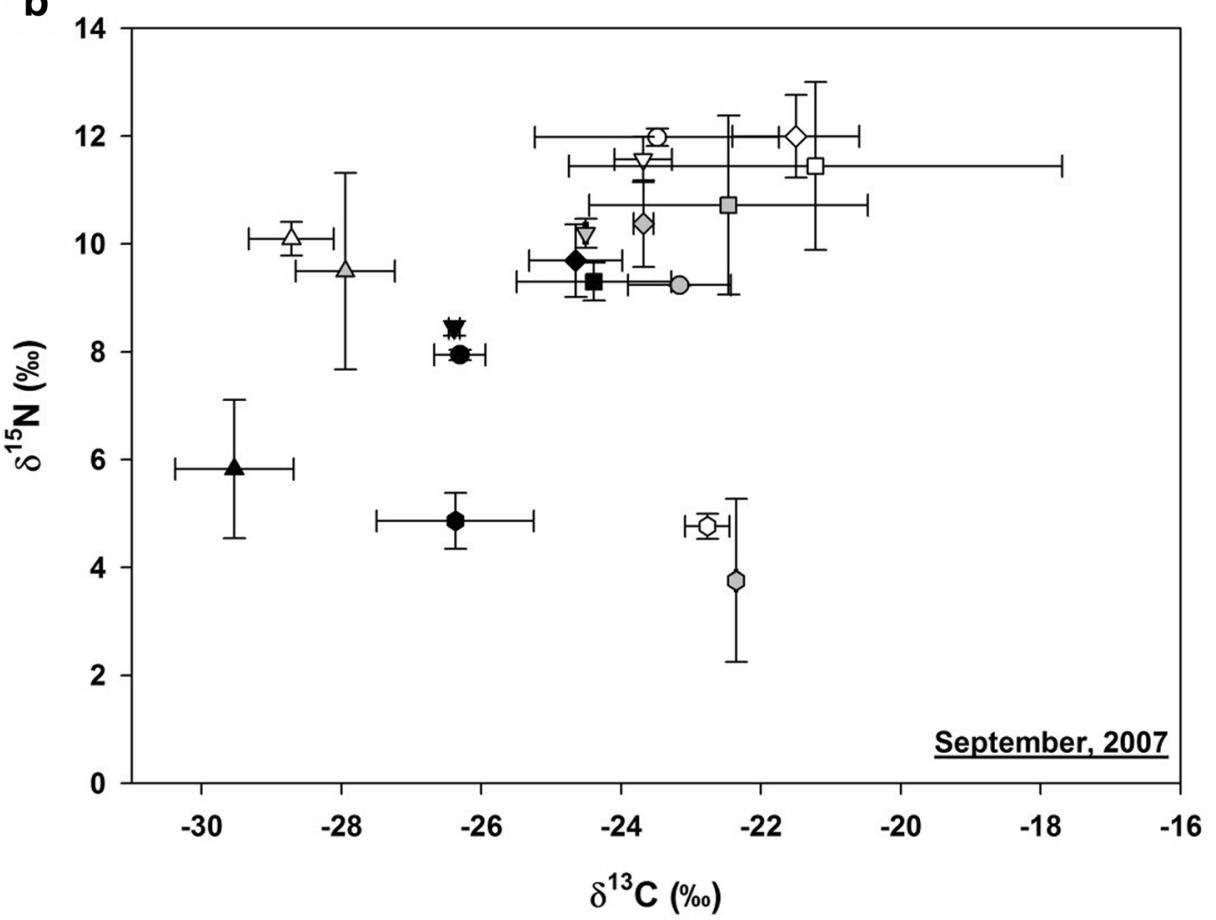

Group I - St. 1

Group II - St. 1

Group III - St. 1

Group IV - St. 1

A. subfragilis - St. 1

- Detrital sediment - St. 1

O Group I - St. 2

$\nabla \quad$ Group II - St. 2

Group III - St. 2

$\triangle \quad P$. communis - St. 2

- Detrital sediment - St. 2

O Group I - St. 3

$\nabla \quad$ Group II - St. 3

G Group III - St. 3

$\diamond \quad$ Group IV - St. 3

$\triangle \quad P$. communis - St. 3

- Detrital sediment - St. 3

\begin{tabular}{ll} 
- & Group I - St. 1 \\
- & Group II - St. 1 \\
- & Group III - St. 1 \\
\hline & S.
\end{tabular}

- S. subfragilis - St. 1

- Detrital sediment - St. 1

- Group I - St. 2

$\nabla \quad$ Group II - St. 2

$\square \quad$ Group III - St. 2

$\diamond \quad$ Group IV - St. 2

$\triangle \quad P$. communis - St. 2

- Detrital sediment - St. 2

O Group I - St. 3

$\nabla \quad$ Group II - St. 3

$\square \quad$ Group III - St. 3

$\diamond \quad$ Group IV - St. 3

$\triangle \quad$ B. planiculmis - St. 3

O Detrital sediment - St. 3

Fig. $3 \delta^{13} \mathrm{C}$ and $\delta^{15} \mathrm{~N}$ diagram of the Han River estuary wetland $\mathbf{a}$ in the early season after hibernation (May 2007) and $\mathbf{b}$ in the active season of foraging (September 2007)

community. Sesarma dehaani had spatial differences in the isotopic signature, showing patterns similar to those of the benthic consumers, including sesarmid crabs, along the salinity gradient in estuarine ecosystems (Table 1 and Fig. 2, Bouillon et al. 2004; Doi et al. 2005;
Bergamino and Richoux 2015). Our results showed that the $\delta^{13} \mathrm{C}$ value of $S$. dehaani was significantly lower in the upper region (site 1) compared to that in the other lower regions, supporting the findings of a previous study in which stable isotope analysis was conducted for 
Table 2 Results of MANOVA based on the values of $\delta^{13} \mathrm{C}$ and $\delta^{15} \mathrm{~N}$ of Sesarma dehaani grouped by carapace width among the different sites in May and September 2007

\begin{tabular}{|c|c|c|c|c|c|c|c|c|c|c|}
\hline \multirow[t]{2}{*}{ Size group } & \multicolumn{5}{|c|}{ May 2007} & \multicolumn{5}{|c|}{ September 2007} \\
\hline & Lambda & p & Sites & $T^{2}$ & $p$ & Lambda & $p$ & Sites & $T^{2}$ & $p$ \\
\hline \multirow[t]{3}{*}{ Group I-II } & 0.067 & $<0.001$ & St.1-St.2 & 14.424 & 0.001 & 0.022 & $<0.001$ & St.1-St.2 & 40.744 & $<0.001$ \\
\hline & & & St.2-St.3 & 14.384 & 0.001 & & & St.2-St.3 & 27.125 & $<0.001$ \\
\hline & & & St.1-St.3 & 59.395 & $<0.001$ & & & St.1-St.3 & 136.352 & $<0.001$ \\
\hline \multirow[t]{3}{*}{ Group III-IV } & 0.174 & 0.002 & St.1-St.2 & 5.154 & 0.032 & 0.279 & 0.003 & St.1-St.2 & 3.311 & 0.072 \\
\hline & & & St.2-St.3 & 1.654 & 0.245 & & & St.2-St.3 & 3.234 & 0.075 \\
\hline & & & St.1-St.3 & 16.634 & 0.001 & & & St.1-St.3 & 15.176 & 0.001 \\
\hline
\end{tabular}

benthic consumers in three different vegetated reaches with salinity gradients in a temperate region (Bergamino and Richoux 2015) as well as those of other studies on mangrove ecosystems (Bouillon et al. 2004). Similarly, the $\delta^{15} \mathrm{~N}$ values of crabs in this study were higher in the lower regions than in the upper region.

In contrast to mangrove ecosystems in tropical and subtropical regions which have been the main sites for studying the interactions between the mangroves and sesarmid crabs, the sites selected in the present study were located in a temperate region, experiencing four distinctive seasons including severe periods of winter. Thus, S. dehaani could begin feeding activity from spring after hibernation unlike in the Asian mangrove ecosystems where Sesarmidae crabs can do foraging activity in all the seasons (Mfilinge and Tsuchiya 2008; Poon et al. 2010). The seasonal changes in the stable isotope signatures of consumers may reflect their food source accumulated through annual variations under given environmental conditions (Grey et al. 2001; Bergamino and Richoux 2015). The changes in the frequency distribution of $\delta^{13} \mathrm{C}$ for $S$. dehaani from spring to fall were distinct between the small- and large-sized groups in the Han River estuary. The $\delta^{13} \mathrm{C}$ values of small-sized crabs, especially in upper sites, tended to shift toward lower values compared to those of large crabs having wide ranges of $\delta^{13} \mathrm{C}$ or in the opposite direction (data not shown). Based on our results, we inferred that $S$. dehaani show different patterns in consuming primary carbon sources depending on their size as well as on the surrounding circumstances in their habitats.

In September, $S$. dehaani exhibited larger variations in the stable isotope signatures compared to that in May, soon after hibernation, especially at sites 2 and 3 (Fig. 3). In a feeding experiment, a sesarmid crab, S. cinereum, consumed not only a particular diet but several diets, when alternative diets were supplied (Buck et al. 2003). Accordingly, we interpret that the crabs exploit a wide range of food resources available locally (e.g., insects and plant materials) as well as those imported from the river and coastal regions in fall after the monsoon rain in

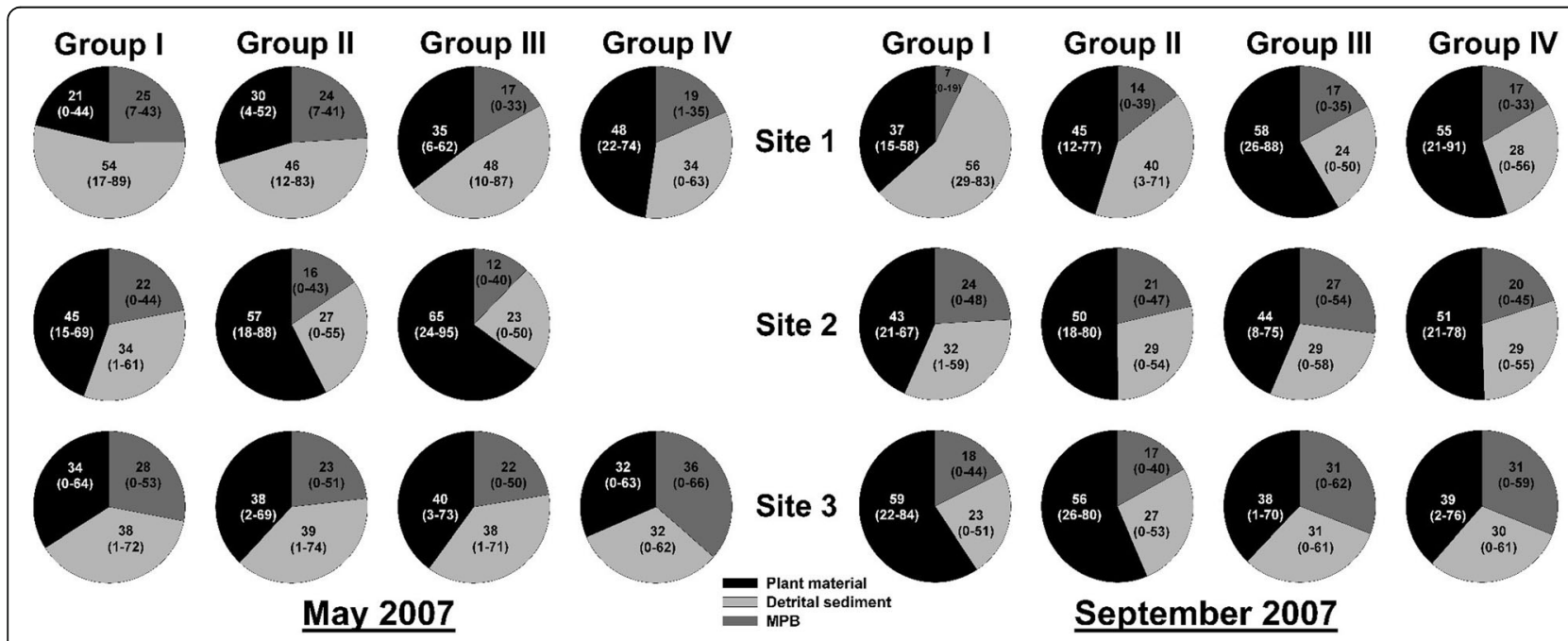

Fig. 4 Mean percentage contributions (95\% credibility interval) of food sources (plant materials, sediment, and microphytobenthos; MPB) to Sesarma dehaani at the three studied sites of the Han River estuary in May and September 2007 


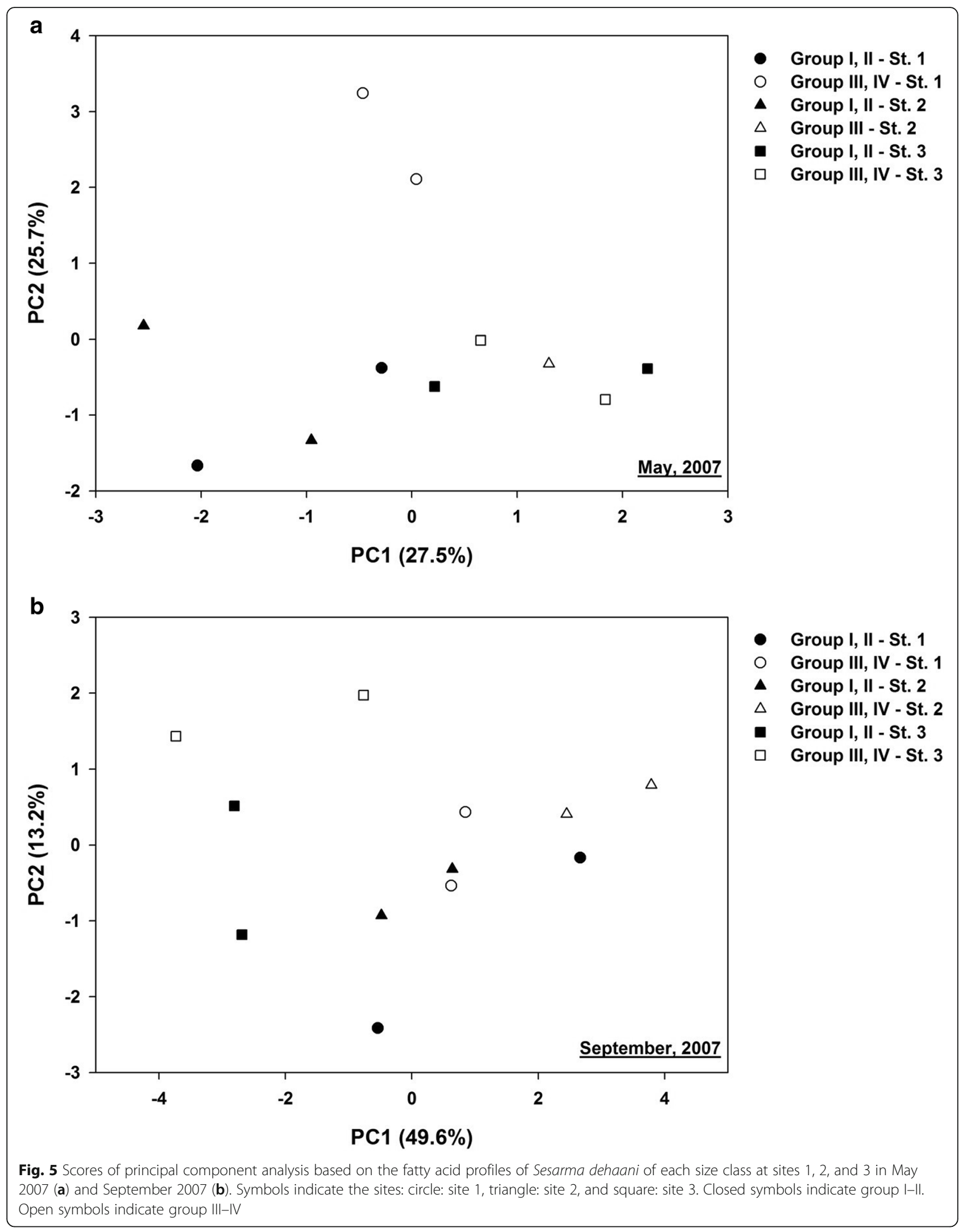




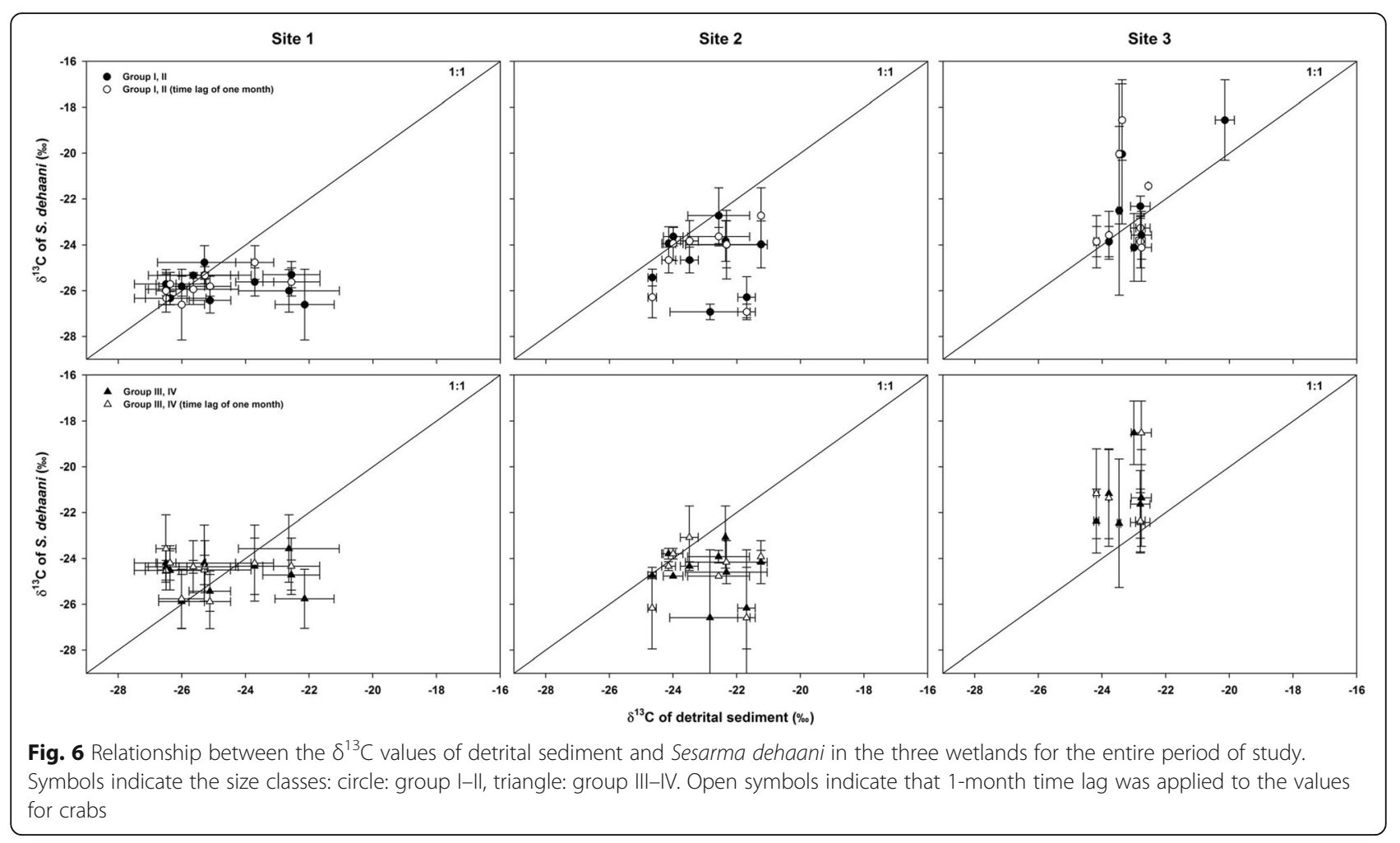

summer. The differences in the $\delta^{13} \mathrm{C}$ and $\delta^{15} \mathrm{~N}$ values among the sites became clearer mainly in small-sized groups possibly because of restriction on handling and access to alternative diets compared to that in the case of groups with large size (Table 2, Buck et al. 2003; Pahlas 2013).

The results of the stable isotope mixing modeling using SIAR demonstrated that plant materials were consumed more compared to the sediment as the size of crabs became larger at site 1, where Salix community contributed to high primary productivity (Fig. 4, Han et al. 2010). Moreover, this ontogenic shift in the feeding habit was enhanced over time because of high production of plant litter (Han et al. 2012). Similarly, at site 2 in May, large crabs utilized the plant materials more than did the small ones. However, at site 2 and 3 in September and at site 3 in May, the diets of large crabs were not dominated by plant materials, which was attributable to low inputs of plant material compared to that at site 1 .

In agreement with the results of SIAR modeling, the FA profiles of the crabs reflected their diets, including the plant source, sediment, and MPB, and were distinct on the PCA plots among the size classes at each site, except for the crabs at site 3 in May, which could not be discriminated by size as in the case of isotopic modeling (Fig. 5). Specifically, the FA content of $18: 3 \omega 3$, a biomarker of plant materials (Dalsgaard et al. 2003), was a major factor to separate size groups based on PCA loadings, indicating that the plant diet might make an important difference in the feeding by different-sized crabs (data not shown).

There was incongruence between the results of the isotopic modeling and FA analysis, for example, that in the site 2 and 3 in September. In this study, the literature values were employed for the SIAR modeling for discrimination factors of diet: the plant material referred to mangrove leaves $\left(3.5 \% \circ \pm 1.5 \%\right.$ and $4 \%$ for $\delta^{13} \mathrm{C}$ and $\delta^{15} \mathrm{~N}$, respectively), sediment $\left(0.4 \%\right.$ and $2.3 \%$ for $\delta^{13} \mathrm{C}$ and $\delta^{15} \mathrm{~N}$, respectively), and MPB referred to global average (Kristensen et al. 2017). However, the discrimination factors of prey for consumers showed different values in the type of tissue and species (McCutchan et al. 2003). Furthermore, the isotopic values of MPB appeared to be influenced by season and location (Bergamino and Richoux 2015). To increase the validity of the estimated contribution of diets for S. dehaani using the isotopic modeling, we should apply proper discrimination values of plant materials, sediment, and MPB used in this study in addition to surveying the other potential diets that we might have missed, in a future study. Another probability is that the separation between sexes was not considered in the present study. Previous field surveys and feeding experiments have shown that the male sesarmid crabs exploited their diets, such as mangrove leaves and animal prey, differently in comparison to the female ones (Kyomo 1992; Buck et al. 2003; Erickson et al. 2003). On the other hand, on the basis of gut content analysis, Poon et al. (2010) reported 
that a sesarmid crab, Perisesarma bidens, did not show sex-related differences in consuming diets at mangrove sites for a year. In addition, the crabs that we analyzed in this study might not represent their size group because of individual variations.

Several studies have demonstrated that sesarmid crabs mainly utilize plant material with sediment as nutrient sources, especially in mangrove ecosystems (Lee 1998; Kristensen et al. 2017). Our results support those of previous studies showing that large sesarmid crabs exploit plant materials more compared to the small individuals in a feeding experiment and a mangrove ecosystem (Emmerson and McGwynne 1992; Pahlas 2013). However, we suggest that these feeding habits may be expected in an ecosystem where sufficient supply of plant material is available like at site 2 and particularly at site 1 in this study, based on our results as well as those obtained in mangrove ecosystems.

Another potential diet-sediment-has been utilized for nutrient balance in terms of stoichiometric ratios in sesarmid crabs (Kristensen et al. 2017). Bouillon et al. (2004) showed that $\delta^{13} \mathrm{C}$ of sesarmid crabs have high correlations with those of sediment in various mangrove forests. In this study, site 1 and site 2, which were more vegetated and located in the upper regions as compared to site 3, showed similar results, especially in the small-sized groups (group I and II) (Fig. 6). However, $\delta^{13} \mathrm{C}$ of the sediment and $S$. dehaani collected at the same time did not show strong correlations (Spearman correlation test on groups I and II: $p=0.85, r_{\mathrm{s}}=-0.06$ for site 1 and $p=0.91, r_{\mathrm{s}}=-0.04$ for site 2). The diets fed by consumers take time to be assimilated and accumulated in their bodies, causing time delay in stable isotope signature. In feeding experiments tracing stable isotope signatures of crabs and their food sources (detritus and litter), it took 3 weeks or more to detect the influences of food sources (Dittel et al. 2000; Herbon and Nordhaus 2013). Considering assimilation and accumulation time in crabs, we put a 1-month time lag between $\delta^{13} \mathrm{C}$ of sediment and crabs, which led to higher correlations except for the frozen sediment period (November and March) (Spearman correlation test on group I and II: $p<0.05, r_{\mathrm{s}}=0.68$ for site 1 and $p<0.05, r_{\mathrm{s}}=0.79$ for site 2). Freezing of sediment is site-specific even during the same period because of salinity gradient along the upper and lower estuarine regions, which influences the food availability for crabs. The surface sediment contains plant detritus, microphytobenthos, and organic matter from river and coastal regions which are drawn into the estuarine ecosystems (Matson and Brinson 1990). In the upper regions, especially at site 1 , the $\delta^{13} \mathrm{C}$ value for sediment might mainly be attributable to the plant-derived organic matter based on negative relations between the $\mathrm{C} / \mathrm{N}$ ratios and $\delta^{13} \mathrm{C}$ of the sediment over time (data not shown, Matson and Brinson 1990; Bouillon et al. 2003, 2004). The sediment at site 3 exhibited higher value of $\delta^{13} \mathrm{C}$ compared to those in the upper regions indicating the influences of marine source (Matson and Brinson 1990; Bouillon et al. 2004).

Our results show that $\delta^{13} \mathrm{C}$ of crabs in the upper regions were lower than those in the lower wetland (Fig. 2). These results support the findings of previous studies wherein food sources of terrestrial origin were the major sources to the primary consumers in the upper estuary, whereas phytoplankton and food sources of marine origin became important in the lower estuary (Lautenschlager et al. 2014; Careddu et al. 2015; Claudino et al. 2015). Based on previous studies on mangrove ecosystems, sesarmid crabs appear to consume plant materials directly or indirectly (Bouillon et al. 2004) and exhibit high feeding activity on sediment (Skov and Hartnoll 2002). Based on the dietary shift in different size groups observed in this study, we infer that the small sesarmid crabs might utilize detritus of plant material on sediment relying on the surrounding circumstances in contrast to the larger ones which can directly access leaves on branches by climbing the trees (Pahlas 2013) and can handle large animal prey (Buck et al. 2003).

\section{Conclusions}

In conclusion, we determined the contributions of major food sources for $S$. dehaani, which is a dominant consumer species in the Han River estuary, where human influences are low. Food sources of $S$. dehaani were mainly influenced by the habitats, especially for small-sized individuals. Sesarma dehaani at site 1 and site 2 in the upper estuary region were influenced more by the food sources of terrestrial origin, whereas the crabs at site 3 , which was more open and closer to the marine environment, were more influenced by the marine phytobenthos. The small-sized individuals were especially more dependent on the sediment sources because of narrow food ranges.

Our results suggest that the overall roles of $S$. dehaani on the nutrient cycles in estuarine wetland ecosystem appear to vary with their sizes and habitats, providing basic data for further studies on energy flow and nutrient cycles in these ecosystems in the temperate regions.

\footnotetext{
Abbreviations

ANOVA: Analysis of variance; DMZ: Demilitarized Zone; FA: Fatty acid; FAMEs: Fatty acid methyl esters; FID: Flame ionization detector; IRMS: Isotope ratio mass spectrometer; MANOVA: Multivariate analysis of varince; MPB: Microphytobenthos; PCA: Principal component analysis;

PTV: Programmable temperature vaporizer; SIAR: Stable isotope analysis in $\mathrm{R}$
}

\section{Acknowledgements}

This research was supported by the Basic Science Research Program through the National Research Foundation of Korea (NRF) funded by the Ministry of Education, Science and Technology (No. 2013R1A1A2011780). 


\section{Funding}

This research was supported by the Basic Science Research Program through the National Research Foundation of Korea (NRF) funded by the Ministry of Education, Science and Technology (No. 2013R1A1A2011780).

\section{Availability of data and materials}

The datasets generated during and/or analyzed during the current study are available from the corresponding author on reasonable request.

\section{Authors' contributions}

DY carried out the field study, performed the analysis, and wrote the manuscript. DH participated in the design of the study, conducted the field study, and reviewed the manuscript. SP conceived the study and reviewed/ edited the manuscript. DY and DH made equal contributions to this study. All authors read and approved the final manuscript.

\section{Ethics approval and consent to participate}

Not applicable.

\section{Consent for publication}

Not applicable.

\section{Competing interests}

The authors declare that they have no competing interests.

\section{Publisher's Note}

Springer Nature remains neutral with regard to jurisdictional claims in published maps and institutional affiliations.

\section{Author details}

'Department of Biological Science, Ajou University, 206, World cup-ro, Yeongtong-gu, Suwon 16499, Republic of Korea. ${ }^{2}$ School of Biological Sciences, Seoul National University, Seoul 08826, Republic of Korea. ${ }^{3}$ Present address: National Marine Biodiversity Institute of Korea, Seocheon 33662, Republic of Korea.

\section{Received: 29 October 2018 Accepted: 7 February 2019}

Published online: 20 February 2019

\section{References}

Antonio ES, Kasai A, Ueno M, Ishihi Y, Yokoyama H, Yamashita Y. Spatial-temporal feeding dynamics of benthic communities in an estuary-marine gradient. Estuar Coast Shelf Sci. 2012:112:86-97.

Baek KO, Yim DH. Flow characteristics induced by shift and modification of submerged weir at Han River estuary. J Kor Soc Civil Eng. 2011;31:109-19.

Bergamino L, Richoux NB. Spatial and temporal changes in estuarine food web structure: differential contributions of marsh grass detritus. Estuar Coasts. 2015;38:367-82.

Bouillon S, Dahdouh-Guebas F, Rao AWS, Koedam N, Dehairs F. Sources of organic carbon in mangrove sediments: variability and possible ecological implications. Hydrobiologia. 2003;495:33-9.

Bouillon S, Moens T, Overmeer I, Koedam N, Dehairs F. Resource utilization patterns of epifauna from mangrove forests with contrasting inputs of local versus imported organic matter. Mar Ecol Prog Ser. 2004;278:77-88.

Buck TL, Breed GA, Pennings SC, Chase ME, Zimmer M, Carefoot TH. Diet choice in an omnivorous salt-marsh crab: different food types, body size, and habitat complexity. J Exp Mar Biol Ecol. 2003;292:103-16.

Careddu G, Costantini ML, Calizza E, Carlino P, Bentivoglio F, Orlandi L, Rossi L. Effects of terrestrial input on macrobenthic food webs of coastal sea are detected by stable isotope analysis in Gaeta Gulf. Estuar Coast Shelf Sci. 2015;154:158-68

Cherel Y, Hobson KA, Weimerskirch $\mathrm{H}$. Using stable-isotope analysis of feathers to distinguish moulting and breeding origins of seabirds. Oecologia. 2000;122:155-62.

Choy EJ, An S, Kang CK. Pathways of organic matter through food webs of diverse habitats in the regulated Nakdong River estuary (Korea). Estuar Coast Shelf Sci. 2008;78:215-26.

Claudino MC, Pessanha ALM, Araújo FG, Garcia AM. Trophic connectivity and basal food sources sustaining tropical aquatic consumers along a mangrove to ocean gradient. Estuar Coast Shelf Sci. 2015;167:45-55.
Dalsgaard J, John MS, Kattner G, Müller-Navarra D, Hagen W. Fatty acid trophic markers in the pelagic marine environment. Adv Mar Biol. 2003;46:225-340.

Delaporte M, Soudant P, Moal J, Kraffe E, Marty Y, Samain JF. Incorporation and modification of dietary fatty acids in gill polar lipids by two bivalve species Crassostrea gigas and Ruditapes philippinarum. Comp Biochem Physiol A Mol Integr Physiol. 2005;140:460-70.

Dittel Al, Epifanio CE, Schwalm SM, Fantle MS, Fogel ML. Carbon and nitrogen sources for juvenile blue crabs Callinectes sapidus in coastal wetlands. Mar Ecol Prog Ser. 2000;194:103-12.

Doi H, Matsumasa M, Toya T, Satoh N, Mizota C, Maki Y, Kikuchi E. Spatial shifts in food sources for macrozoobenthos in an estuarine ecosystem: carbon and nitrogen stable isotope analyses. Estuar Coast Shelf Sci. 2005;64:316-22.

Emmerson WD, McGwynne LE. Feeding and assimilation of mangrove leaves by the crab Sesarma meinerti de Man in relation to leaf-litter production in Mgazana, a warm-temperate southern African mangrove swamp. J Exp Mar Biol Ecol. 1992;157:41-53.

Erickson AA, Saltis M, Bell SS, Dawes CJ. Herbivore feeding preferences as measured by leaf damage and stomatal ingestion: a mangrove crab example. J Exp Mar Biol Ecol. 2003;289:123-38.

Grey J, Jones RI, Sleep D. Seasonal changes in the importance of the source of organic matter to the diet of zooplankton in Loch Ness, as indicated by stable isotope analysis. Limnol Oceanogr. 2001;46:505-13.

Han D, Yang D, Lee EJ, Park S. Food web structure in a Salix subfragilis dominated wetland in Hangang estuary using stable isotopes and fatty acid biomarkers. Anim Cells Syst. 2012;16:162-71.

Han D, Yoo JW, Yoo Y, Lee EJ, Park S. Aboveground primary productivity of Salix nipponica and secondary productivity of Sesarma dehaani at Janghang Wetland in Han River Estuary. Kor J Limnol. 2010;43:298-306.

Herbon CM, Nordhaus I. Experimental determination of stable carbon and nitrogen isotope fractionation between mangrove leaves and crabs. Mar Ecol Prog Ser. 2013;490:91-105.

Kattner G, Fricke HS. Simple gas-liquid chromatographic method for the simultaneous determination of fatty acids and alcohols in wax esters of marine organisms. J Chromatogr A. 1986;361:263-8.

Kristensen E, Bouillon S, Dittmar T, Marchand C. Organic carbon dynamics in mangrove ecosystems: a review. Aquat Bot. 2008:89:201-19.

Kristensen E, Lee SY, Mangion P, Quintana CO, Valdemarsen T. Trophic discrimination of stable isotopes and potential food source partitioning by leaf-eating crabs in mangrove environments. Limnol Oceanogr. 2017;62(5):2097-112.

Kyomo J. Variations in the feeding habits of males and females of the crab Sesarma intermedia. Mar Ecol Prog Ser. 1992;83:151-5.

Lautenschlager AD, Matthews TG, Quinn GP. Utilization of organic matter by invertebrates along an estuarine gradient in an intermittently open estuary. Estuar Coast Shelf Sci. 2014;149:232-43.

Lee SY. Ecological role of grapsid crabs in mangrove ecosystems: a review. Mar Freshw Res. 1998:49:335-43.

Lee SY. Carbon dynamics of Deep Bay, eastern Pearl River estuary, China. II: trophic relationship based on carbon-and nitrogen-stable isotopes. Mar Ecol Prog Ser. 2000;205:1-10.

Lee SY, Primavera JH, Dahdouh-Guebas F, McKee K, Bosire JO, Cannicci S, Diele K, Fromard F, Koedam N, Marchand C, Mendelssohn I, Mukherjee N, Record S. Ecological role and services of tropical mangrove ecosystems: a reassessment. Glob Ecol Biogeogr. 2014;23:726-43.

Matson EA, Brinson MM. Stable carbon isotopes and the C: N ratio in the estuaries of the Pamlico and Neuse Rivers, North Carolina. Limnol Oceanogr. 1990:35:1290-300.

McCutchan JH, Lewis WM, Kendall C, McGrath CC. Variation in trophic shift for stable isotope ratios of carbon, nitrogen, and sulfur. Oikos. 2003;102:378-90.

Mfilinge PL, Tsuchiya M. Effect of temperature on leaf litter consumption by grapsid crabs in a subtropical mangrove (Okinawa, Japan). J Sea Res. 2008:59:94-102.

Ministry of Environment Korea. Plan of maintenance of the Han River Estuary. Seoul; 2007. p. 362

Nagelkerken I, Blaber SJM, Bouillon S, Green P, Haywood M, Kirton LG, Meynecke JO, Pawlik J, Penrose HM, Sasekumar A, Somerfield PJ. The habitat function of mangroves for terrestrial and marine fauna: a review. Aquat Bot. 2008;89:155-85.

Pahlas JM. Size dependent shifts in the diet of the mangrove tree crab, Aratus pisonii, as indicated by $\delta^{13} \mathrm{C} \& \delta^{15} \mathrm{~N}$ from a mangrove ecosystem in Indian River Lagoon, FL. Ph.D. In: Thesis. Athens: University of Georgia; 2013. 
Park GS. Salinity distribution and ecological environment of Han river estuary. J Kor Wetl Soc. 2004;6:149-66.

Parnell AC, Inger R, Bearhop S, Jackson AL. Source partitioning using stable isotopes: coping with too much variation. PLoS One. 2010;5:e9672.

Peterson BJ. Stable isotopes as tracers of organic matter input and transfer in benthic food webs: a review. Acta Oecol. 1999;20:479-87.

Poon DY, Chan BK, Williams GA. Spatial and temporal variation in diets of the crabs Metopograpsus frontalis (Grapsidae) and Perisesarma bidens (Sesarmidae): implications for mangrove food webs. Hydrobiologia. 2010;638:29-40.

$R$ Core Team. R: a language and environment for statistical computing, version 3. 2.2. Vienna: R Foundation for Statistical Computing; 2014. https://www.Rproject.org

Skov MW, Hartnoll RG. Paradoxical selective feeding on a low-nutrient diet: why do mangrove crabs eat leaves? Oecologia. 2002;131:1-7.

Thongtham N, Kristensen E, Puangprasan SY. Leaf removal by sesarmid crabs in Bangrong mangrove forest, Phuket, Thailand; with emphasis on the feeding ecology of Neoepisesarma versicolor. Estuar Coast Shelf Sci. 2008;80:573-80.

van den Berg RA, Hoefsloot HC, Westerhuis JA, Smilde AK, van der Werf MJ. Centering, scaling, and transformations: improving the biological information content of metabolomics data. BMC Genomics. 2006;7:142.

Vander Zanden MJ, Chandra S, Park S, Vadeboncoeur Y, Goldman CR. The relative efficiencies of benthic and pelagic trophic pathways in a subalpine lake. Can J Fish Aquat Sci. 2006;63:2608-20.

Werry J, Lee SY. Grapsid crabs mediate link between mangrove litter production and estuarine planktonic food chains. Mar Ecol Prog Ser. 2005;293:165-76.

Ready to submit your research? Choose BMC and benefit from:

- fast, convenient online submission

- thorough peer review by experienced researchers in your field

- rapid publication on acceptance

- support for research data, including large and complex data types

- gold Open Access which fosters wider collaboration and increased citations

- maximum visibility for your research: over $100 \mathrm{M}$ website views per year

At $\mathrm{BMC}$, research is always in progress.

Learn more biomedcentral.com/submissions 